\title{
Absence of a Grass/Fire Cycle in a Semiarid Grassland: Response to Prescribed Fire and Grazing
}

\author{
Christopher J. McDonald ${ }^{1}$ and Guy R. McPherson ${ }^{2}$ \\ Authors are ${ }^{1}$ Natural Resource Advisor, University of California, Cooperative Extension, San Bernardino, CA 92415, USA; and ${ }^{2}$ Professor Emeritus, \\ School of Natural Resources and the Environment, University of Arizona, Tucson, AZ 85721, USA.
}

\begin{abstract}
Many nonnative invasive grasses alter fire regimes to their own benefit and the detriment of native organisms. In southern Arizona the nonnative Lehmann lovegrass (Eragrostis lehmanniana Nees) dominates many semiarid grasslands where native grasses were abundant. Managers are wary of using prescribed fire in this fire-prone community partly due to the perceived effects of a grass/fire cycle. However, examples of the grass/fire cycle originate in ecosystems where native plants are less firetolerant than grasses and the invasive plant does not mimic the physiognomy of the native community. We investigate the effects of prescribed fire and livestock grazing on a semiarid grassland community dominated by a nonnative invasive grass. Lehmann lovegrass does not appear to alter the fire regime of semiarid grasslands to the detriment of native plants. Prescribed fire reduced the abundance of Lehmann lovegrass for 1 to $2 \mathrm{yr}$ while increasing abundance of native grasses, herbaceous dicotyledons and fall richness, and diversity. Effects of livestock grazing were less transformative than the effects of fire in this long-grazed area, but grazing negatively affected native plants as did the combination of prescribed fire and livestock grazing. Although Lehmann lovegrass produces more fuel than native plants, fire frequency in semiarid grasslands appears to be limited by the paucity of above-average precipitation, which constrains high fuel loads. In addition, many native grasses tolerate high temperatures produced by Lehmann lovegrass fires. Consistent with previous research, fire does not promote the spread of Lehmann lovegrass, and more importantly human alteration of the fire regime is greater than the nominal effects of Lehmann lovegrass introduction on the fire regime.
\end{abstract}

\begin{abstract}
Resumen
Muchos de los pastos invasores exóticos alteran el régimen del fuego para su propio beneficio y en detrimento de los organismos nativos. En el sur de Arizona, el pasto exótico Eragrostis lehmanniana Nees es dominante en muchos pastizales semiáridos en los que los pastos nativos fueron abundantes. Existe una aprensión en el uso del fuego en estas comunidades susceptibles a incendios en parte debido a los efectos percibidos de un ciclo de pasto/fuego. Sin embargo, los ejemplos del ciclo pasto/fuego son originarios de ecosistemas en los que las especies nativas son menos tolerantes al fuego que los pastos y en los que la fisonomía de la planta invasora es diferente al de la comunidad nativa. Se investigaron los efectos de quemas prescriptas y el pastoreo del ganado en una comunidad de pastizal semiárido dominada por un pasto exótico invasor. E. lehmanniana no aparenta cambiar el régimen del fuego de pastizales semiáridos en detrimento de las plantas nativas. Las quemas prescriptas redujeron la abundancia de E. lehmanniana durante uno o dos años favoreciendo el aumento en la abundancia de pastos nativos, dicotiledóneas herbáceas, y la riqueza y diversidad en el otoño. Los efectos del pastoreo del ganado fueron menos transformadores que los efectos del fuego en esta área pastoreada desde hace mucho tiempo, pero tanto el pastoreo sólo o en combinación con el fuego afectaron a las plantas nativas negativamente. Si bien E. lehmanniana produce más combustible que las plantas nativas, la frecuencia del fuego en pastizales semiáridos parece estar limitada por la escasez de precipitaciones anuales superiores a la media que restringen la generación de altas cargas de combustible. Además, muchos pastos nativos toleran las altas temperaturas de los fuegos inducidos por E. lehmanniana. En consonancia con investigaciones previas, el fuego no promueve la propagación de E. lehmanniana, y de mayor importancia es el hecho de que la alteración humana del régimen del fuego es mayor que los efectos nominales de la introducción de E. lehmanniana.
\end{abstract}

Key Words: Arizona, Eragrostis lehmanniana, invasive grasses, Lehmann lovegrass, livestock grazing, native plants

\section{INTRODUCTION}

The introduction of nonnative species and land-use impacts are two prominent disturbances that threaten biodiversity (Wilcove

This research was funded in part by the US Forest Service, Rocky Mountain Research Station under joint venture agreement number 03-JV11221615-215

At the time of research, McDonald was a graduate student, School of Natural Resources, University of Arizona, Tucson, AZ 85721, USA.

Correspondence: Christopher McDonald, University of California, Cooperative Extension, $777 \mathrm{E}$. Rialto, San Bernardino, CA 92415, USA. Email: cjmcdonald@ucdavis.edu

Manuscript received 5 May 2010; manuscript accepted 7 April 2011. et al. 1998). The effects of nonnative invasive species on native plant communities and fire regimes are well documented, particularly the effects of grass introductions (D'Antonio and Vitousek 1992; Brooks et al. 2004; Zouhar et al. 2008). Management strategies also can influence the preservation of biodiversity by altering extirpation and extinction rates (Pimm and Lawton 1998). In southern Arizona, the introduction of Lehmann lovegrass (Eragrostis lehmanniana Nees) coupled with more than a century of intensive management has resulted in a loss of biodiversity on multiple trophic levels (Bock et al. 1986).

Many nonnative plants have the ability to change the fire regime by altering the frequency, type, extent, timing, intensity, 
and/or severity of fires (Zouhar et al. 2008). These specific aspects of the fire regime can be increased, as in the case of the grass/fire cycle, or decreased, as evidenced by the invasion of the succulent Carpobrotus edulis (L.) L. Bolus potentially limiting fire frequency and spread (Brooks et al. 2004). Many examples describe or extrapolate the effects of nonnative invasive species in nongrass dominated ecosystems, shrublands, and woodlands (D'Antonio and Vitousek 1992; Brooks et al. 2004; Zouhar et al. 2008). The native plants are slower growing and less tolerant of fire than invasive grasses, and in general the physiognomy of the invasive plants and the native community do not match. Few studies have directly examined alteration of fire regimes due to invasive grasses in fire-prone grasslands where there is a better match in physiognomy. Fewer have measured medium to long-term cover in postfire communities of invasive plants in grasslands, directly linking the entire positive feedback cycle (D'Antonio and Vitousek 1992; Rossiter et al. 2003).

During the late 19th century a large increase in the extent and intensity of livestock grazing began to degrade rangelands in southern Arizona (Crider 1945). A prolonged drought further compounded the shortage of forage and regularly occurring wildfires were suppressed to preserve remaining forage. The combination of these three factors, overgrazing, drought, and fire suppression, dramatically and irreversibly altered many native plant communities in as little as $20 \mathrm{yr}$ (Turner et al. 2003). Lehmann lovegrass, a South African native, was initially seeded on 69000 ha in southern Arizona to decrease erosion rates and it continues to spread to several neighboring states in the southwestern United States and northern Mexico (Anable et al. 1992; Schussman et al. 2006). Lehmann lovegrass has displaced once-abundant native species in many areas of southern Arizona and in some locations the species dominates stands that appear monotypic (Anable et al. 1992).

The historic fire regime in these semiarid grasslands was variable. Because fuels are limited by above-average precipitation (Crimmins and Comrie 2004), fire frequencies would vary. Estimates of the historic fire regime in the southwest United States would depend on location and precipitation, and could vary from "fairly frequent" (Bahre 1991) to every few decades (Wright and Bailey 1982) to possibly nonexistent (Buffington and Herbel 1965). Extent was variable ranging from small to very large because fuels were continuous across some valleys (Bahre 1991). Seasonality of fire was likely in the late spring to early summer when "monsoon" thunderstorms produce abundant lightning and fuel moisture is low (McPherson 1995). The modern fire regime in most semiarid grasslands in the United States is reduced in frequency and extent, with frequencies ranging from every few decades to complete elimination in some areas (Van Auken 2000).

Many other invasive grasses in the grass/fire cycle literature are not similar in physiognomy to the native vegetation they replace (D'Antonio and Vitousek 1992; Brooks et al. 2004; Zouhar et al. 2008). Examples of this phenomenon are numerous: cheat grass (Bromus tectorum L.) is invading shrublands in the western United States (Whisenant 1990); red brome (Bromus madritensis L. ssp. rubens [L.] Husnot) is invading desert shrublands in the southwest United States (Brooks 1999); Gamba grass (Andropogon gayanus Kunth) is much taller and creates higher fuel loads than the native Australian grasses it replaces (Rossiter et al. 2003); and buffelgrass (Pennisetum ciliare [L.] Link syn. Cenchrus ciliaris L.) is invading woodlands in Australia (Miller et al. 2010) and deserts shrublands in southwest North America (Esque and Schwalbe 2002). All of these grasses are in many ways different from the native community and it is predictable that this difference accounts for the altered fire regime.

In contrast, in southern Arizona Lehmann lovegrass has a similar morphology to the native vegetation. The invasion of Lehmann lovegrass into semiarid ecosystems provides a valuable reference point in the dynamics of invasive grasses and alteration of fire regimes. Lehmann lovegrass is tolerant of fire, but unlike the physiognomic mismatches in much of the grass/ fire literature (see table 1 in Brooks et al. 2004 for other examples), native grasses in southern Arizona also are tolerant of fire and are morphologically similar to Lehmann lovegrass. Nonetheless, logic suggests a positive-feedback cycle because Lehmann lovegrass produces more biomass than native plants, is more water-use efficient, remains photosynthetically active throughout the year, has a lower decomposition rate than native grasses, and its seed germination is enhanced by fire (Cox 1984; Ruyle et al. 1988; Sumrall et al. 1991; Frasier and Cox 1994; Fernandez and Reynolds 2000). However, actual demonstration of a positive-feedback cycle requires evidence that invasion by Lehmann lovegrass 1) alters fuel loads and therefore, 2) alters the fire regime. Further, the subsequently altered fire regime must, 3) decrease native plant cover and 4) increase nonnative plant cover (D'Antonio and Vitousek 1992). Lehmann lovegrass can produce more biomass than native grasses, thus postulate 1 has been established (Fernandez and Reynolds 2000). We evaluate the conditions under which this fire-tolerant nonnative grass alters a potentially high-frequency fire regime by measuring if native plant cover decreases after fire (postulate 3 ) and nonnative plant cover increases (postulate 4) in the medium- to long-term. We also use previous fire research to estimate if the fire regime is different in Lehmann lovegrass compared to native-dominated stands (postulate 2).

In addition, using previously documented patterns of Lehmann lovegrass spread and recovery after disturbances, we evaluate the effectiveness of common management techniques to restore and rehabilitate native plant populations. Because Lehmann lovegrass initiates growth before native grasses each spring, prescribed fires during the historical fire season (early summer) could be selectively detrimental to Lehmann lovegrass. In addition, intensive grazing of recently burned Lehmann lovegrass plants may further reduce dominance of lovegrass, to the benefit of native grasses.

\section{MATERIALS AND METHODS}

\section{Study Site}

All treatments were performed on the Santa Rita Experimental Range (SRER) $50 \mathrm{~km}$ south of Tucson, Arizona, in semiarid grasslands dominated by Lehmann lovegrass (lat 31.7484, long 110.837). The SRER has large amounts of historical and recent data on semiarid rangelands and has been a site of significant research on Lehmann lovegrass (McClaran et al. 2003). This site has been grazed for over $100 \mathrm{yr}$, but a perimeter fence was 
constructed to exclude livestock grazing $1 \mathrm{yr}$ before the study began. Mesquite (Prosopis velutina Woot.) had previously encroached the site, but all trees were removed in the 1950s and have recolonized the site in limited quantities. The site is a semiarid mesquite savanna and is dominated by Lehmann lovegrass, while perennial native grasses are sparsely distributed individuals or are limited to small patches (2-10 m diameter) or in areas with increased soil moisture, i.e., washes. Subshrubs compromise a minority of cover. Soils are a BaboquivariCombate complex with the majority of the site containing the Baboquivari soil series. Topsoils are generally dark yellowish brown loamy sand from $0 \mathrm{~cm}$ to $8 \mathrm{~cm}$ with $5-10 \%$ surface gravel, and subsoil is a brown coarse sandy loam to reddish brown coarse sandy clay loam from $8 \mathrm{~cm}$ to $150 \mathrm{~cm}$ (Breckenfeld and Robinett 2003). Precipitation in the Sonoran Desert is bimodal with peaks in the winter and summer. Average annual precipitation at the site is approximately $45 \mathrm{~cm}$, with approximately $20 \mathrm{~cm}$ in the winter (October through April) and $25 \mathrm{~cm}$ occurring during summer (May through September) "monsoons."

\section{Methods}

The 24 plots consisted of 0.25 -ha $(50 \times 50 \mathrm{~m})$ areas with a minimum 40-m buffer between plots for purposes of safety and to ensure independence of plots. Plots were fenced to provide control such that livestock grazing was allowed only after fires were completed. Treatment year and type were randomly assigned to each block and plot. Prescribed-fire and livestock treatments were applied to half the plots in summer of 2005 and again on the remaining 12 plots in summer of 2006. Plots were sampled during fall 2004 through fall 2008.

Objectives were met using a two-factor design with fullfactorial treatment structure; treatments included fire and livestock grazing. Specifically, fire treatments included early summer prescribed fires (late June), when Lehmann lovegrass actively grows while native grasses are dormant, and unburned treatments. The experiment also included two levels of livestock grazing (present and absent) and livestock grazing was confined to the plots. Livestock treatments were initiated after prescribed fires were completed and eight livestock grazed plots for 2-7 d depending on whether the plot was previously treated with fire. The objective was that all plots would have over $80 \%$ utilization rate. If the plot was previously treated with fire, biomass was low thus the duration of grazing necessary to obtain a utilization rate greater than $80 \%$ was $2-$ $4 \mathrm{~d}$. If the plot was unburned, biomass was higher and duration was $4-7 \mathrm{~d}$. The burning-and-then grazing treatment was additive, livestock grazing followed burning by approximately $7 \mathrm{wk}$, and livestock were confined to the plots. The entire experiment was repeated during a second year to account for interannual variability in production, which increases statistical power to detect treatment effects. This design yielded eight treatment combinations ( 2 fire $\times 2$ grazing $\times 2$ yr), each of which is replicated three times, totaling 24 plots.

Community composition was described every fall and spring during the two peaks in biomass, which correspond to the region's bimodal rainfall distribution, with peaks in the summer and winter. To estimate plant species composition, we used the point-intercept method. Plant cover was recorded every $0.5 \mathrm{~m}$ along eight randomly located 25 -m long transects. In 2004 a total of 400 points were collected from each plot.

Production data (aboveground biomass) were collected every fall, which corresponds to peak standing biomass of grasses. We randomly located 10 quadrats $\left(0.5 \mathrm{~m}^{2}\right)$, which were clipped (to $2.5 \mathrm{~cm}$ ) and separated by physiognomic type: grass, litter, and forbs (herbaceous dicotyledons "dicots"). The samples were then dried (at $60^{\circ} \mathrm{C}$ for at least $24 \mathrm{~h}$ ) and weighed for aboveground biomass (to the nearest $0.1 \mathrm{~g}$ ). Litter was defined as detached or loosely attached plant material, which included some easily removed standing dead litter. Some standing dead litter that was not loosely attached was counted as grass biomass. Production of woody plants was not collected, because they did not significantly contribute to fine fuel loads and/or were not abundant in this semiarid grassland.

After completing a pretreatment power analysis, sampling effort was increased. Small-scale variation was high due to the presence of bare patches; for example biomass (measured in $0.5 \mathrm{~m}^{2}$ quadrats) in 2004 ranged from 0 to over $600 \mathrm{~g} \cdot \mathrm{m}^{-2}$ for grasses and litter. Thus for all subsequent data-collection events (2005-2008) the number of points measured was increased from 400 to 500, and biomass sampling increased from 10 to 15 quadrats.

\section{Analysis}

Data met assumptions for analyses after square-root transformation. To test postulates 3 and 4, cover type (Lehmann lovegrass, native grasses, shrubs, dicots, litter, and bare ground) was analyzed with a multiple regression with year, season of sampling, treatment, precipitation, and year treatments were implemented as explanatory variables. Multiple regression analyses were used to detect differences in cover between treatments for different cover types across all years, seasons, precipitation, and year treatments were implemented. Analysis of variance (ANOVA) was used to detect differences between treatments within a single combination of year, season, and year of treatment, which also aids in testing postulates 3 and 4 .

A repeated measures ANOVA (RMANOVA) was used to test differences in biomass between physiognomic groups (grasses, litter, and dicots) and treatments. The effects of treatments on plant species richness between fall and spring sampling seasons were analyzed using multiple regression, and a RMANOVA was used to detect differences in richness between treatments.

A multiple regression was used to examine the effects of varying proportions of Lehmann lovegrass, season of sampling, treatment, year of treatment, and also included appropriate interactions as explanatory variables with Shannon's diversity as the response variable. The relationship between diversity and proportion of Lehmann lovegrass was revealed with a regression analysis.

\section{RESULTS}

\section{Lehmann Lovegrass Cover and Grass/Fire Cycle}

There is no evidence to suggest a postfire increase in nonnative grass cover (postulate 4). Despite profound differences in precipitation between years of treatment, burning treatments did not significantly increase Lehmann lovegrass cover from 

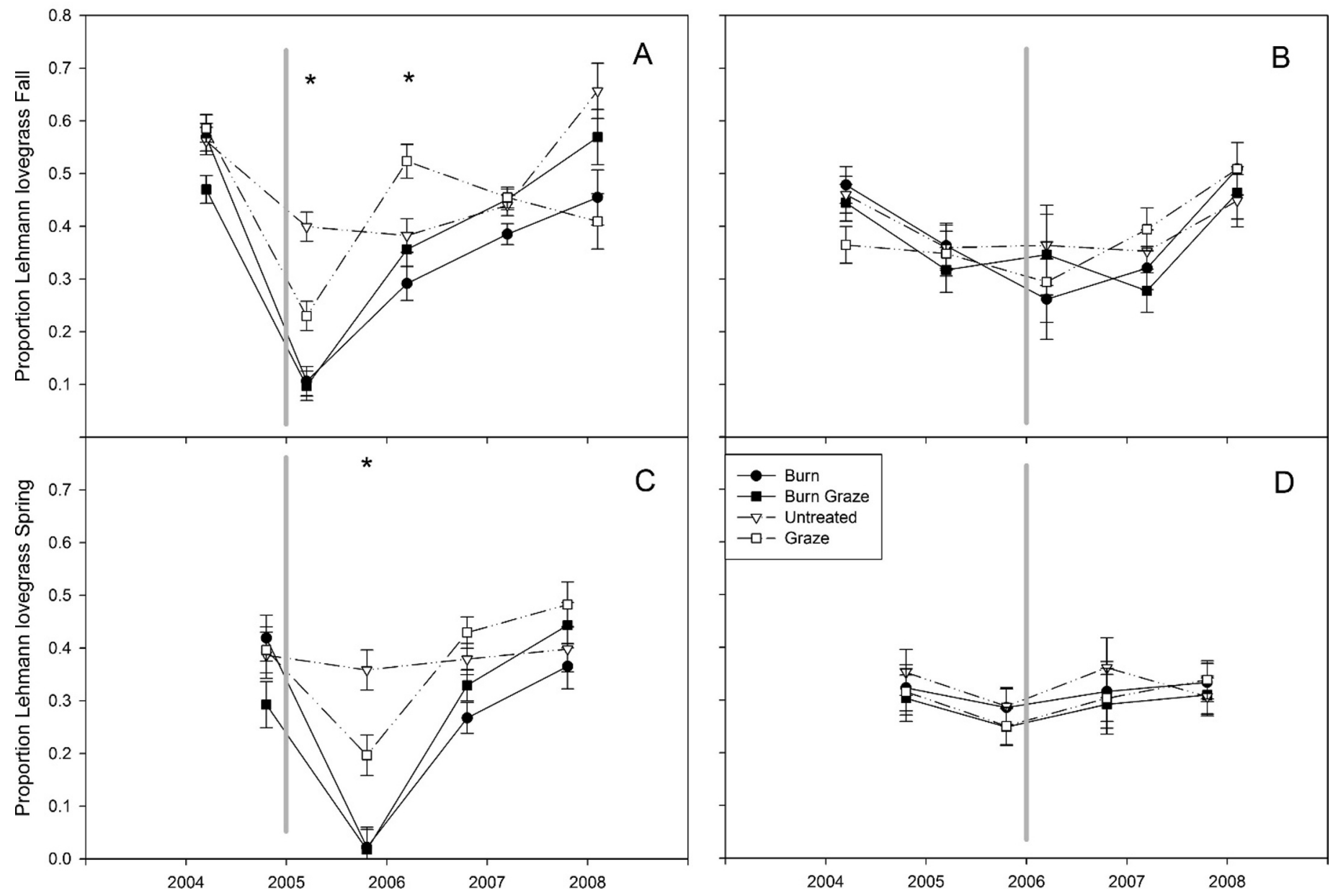

Figure 1. Relative plant cover of Lehmann lovegrass on plots treated with prescribed fire (solid lines, filled circles), livestock grazing (dashed lines, open squares), both prescribed fire and livestock grazing (solid line, filled squares), or were untreated (dashed lines, open triangles) on the Santa Rita Experimental Range 50 km south of Tucson, Arizona. Treatments were implemented in 2005 (left column) or 2006 (right column) and indicated by grey lines. Bars represent standard error. Proportion was measured in both the fall (top row) and spring (bottom row). Asterisk indicates a significant difference between two or more treatments.

2004 to 2008, nor was there a significant increase in Lehmann lovegrass cover from 2004 to 2008 (Fig. 1). There were limited but not statistically significant increases in Lehmann lovegrass cover between 2004 and 2008 on individual plots treated with the combination of fire and livestock grazing as well as on grazed plots, but again these were not statistically significant.

It is possible that on average plots had a near carrying capacity of Lehmann lovegrass, since the average cover of Lehmann lovegrass was $50 \%$ of total cover and $72 \%$ of relative plant cover. Thus, we analyzed cover of Lehmann lovegrass on plots with below average cover. Even when restricted to this subset of plots, there was no significant positive feedback with treatments $(P=0.17)$, thus we find no evidence of an increase in nonnative grasses after fire (postulate 4$)$.

\section{Cover}

Precipitation had the most consistent and significant effect on the cover of Lehmann lovegrass, native grasses, shrubs, dicots, litter, and bare ground (multiple regression $P<0.0001,<0.0001$, $=0.0268,<0.0001,<0.0001$, and $<0.0001$, respectively) . Our data suggest the opposite of postulates 3 and 4 occurred; burning and burning-and-then grazing treatments implemented in 2005 decreased the cover of Lehmann lovegrass for $2 \mathrm{yr}$ (Fig. 1A, opposite of postulate 4) and the burning treatment increased the cover of native grasses (Fig. 2A, opposite of postulate 3), but not the burning-and-then-grazing treatment (Fig. 2A, solid line with squares). The cover of bare ground significantly increased for $3 \mathrm{yr}$ (data not shown). Treatments did not change the cover dicots. The increase in native grasses was found in both annual and perennial species; however, individual species (Urochloa arizonica [Scribn. \& Merr.] O. Morrone and F. Zuloaga, Panicum hirticaule J. Presl., Aristida ternipes Cav., Bouteloua curtipendula [Michx.] Torr., and Heteropogon contortus [L.] P. Beauv. ex Roem. \& Schult.) were not abundant enough across plots to detect statistically significant differences between treatments (mean abundance 6.0\%, 1.8\%, 1.5\%, $1.2 \%$, and $1.1 \%$, respectively). This scarcity also did not allow us to test for differences in biomass between patches of native and invaded grassland.

Treatments implemented in 2006 did not have significant and persistent effects on the cover of Lehmann lovegrass (Figs. 1B and 1D), native grasses (Figs. 2B and 2D), shrubs, 

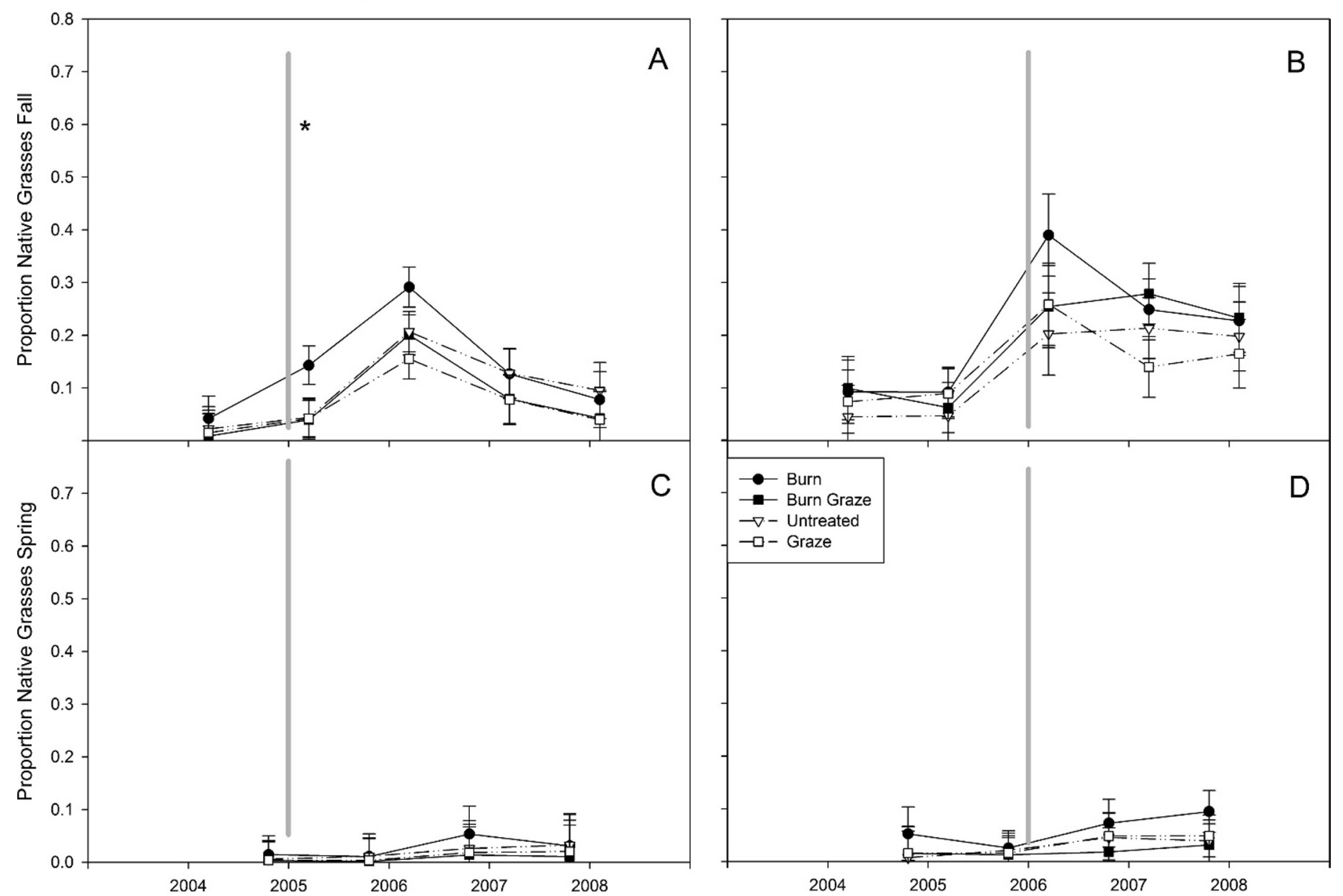

Figure 2. Relative plant cover of native grasses on plots treated with prescribed fire, livestock grazing, both prescribed fire and livestock grazing, or were untreated. Treatment symbols and layout are described in Figure 1.

dicots, and bare ground (data not shown). This was due to near record high summer precipitation causing rapid growth on treated plots.

\section{Precipitation}

Annual precipitation in all but $1 \mathrm{yr}$ was below the historical average (Fig. 3). However, summer precipitation was above average in the $3 \mathrm{yr}$ of the study after treatments were implemented. The most marked decline in winter precipitation occurred in 2005-2006, which was the driest on record (85-yr history), at greater than $80 \%$ below average. The historically low precipitation in the winter of 2006 was followed by an unusually large, $35 \%$, increase in summer precipitation late that summer (sixth wettest September). Thus, plots treated during summer 2005 experienced below-average precipitation for $1 \mathrm{yr}$. In contrast, plots treated in summer 2006 experienced above-average summer precipitation soon after treatments were implemented.

\section{Biomass}

On average, $50 \%$ of aboveground biomass was composed of litter, grasses made up $48 \%$, and dicots were only $2 \%$ (Fig. 4).

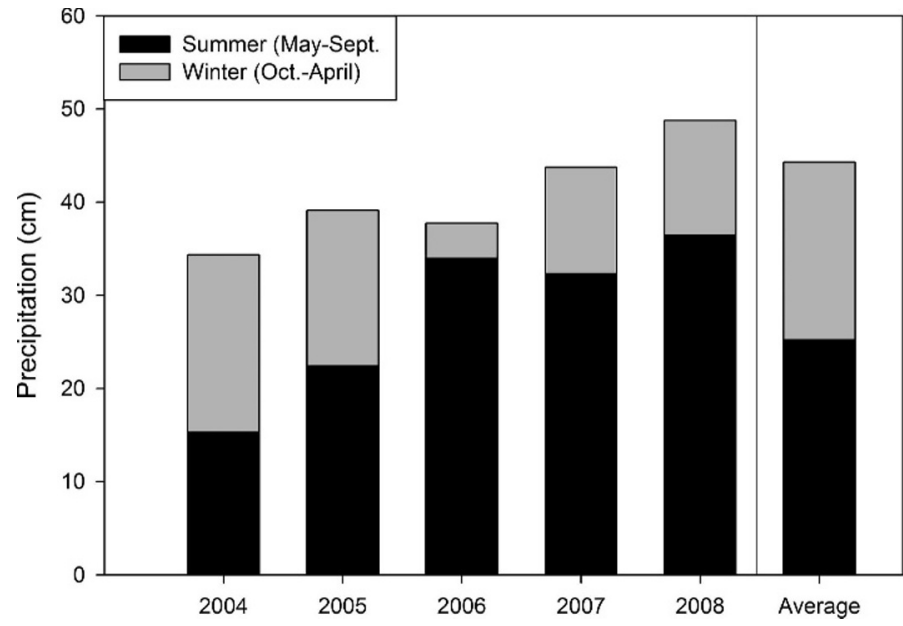

Figure 3. Precipitation from 2004 to 2008 at nearby "Forest" rain station on the Santa Rita Experimental Range, $50 \mathrm{~km}$ south of Tucson in southern Arizona. Summer precipitation (black fill) was from May to September while winter (grey) was from October to April. Average rainfall $(44.4 \mathrm{~cm})$ was calculated from long-term data spanning 19232008. 

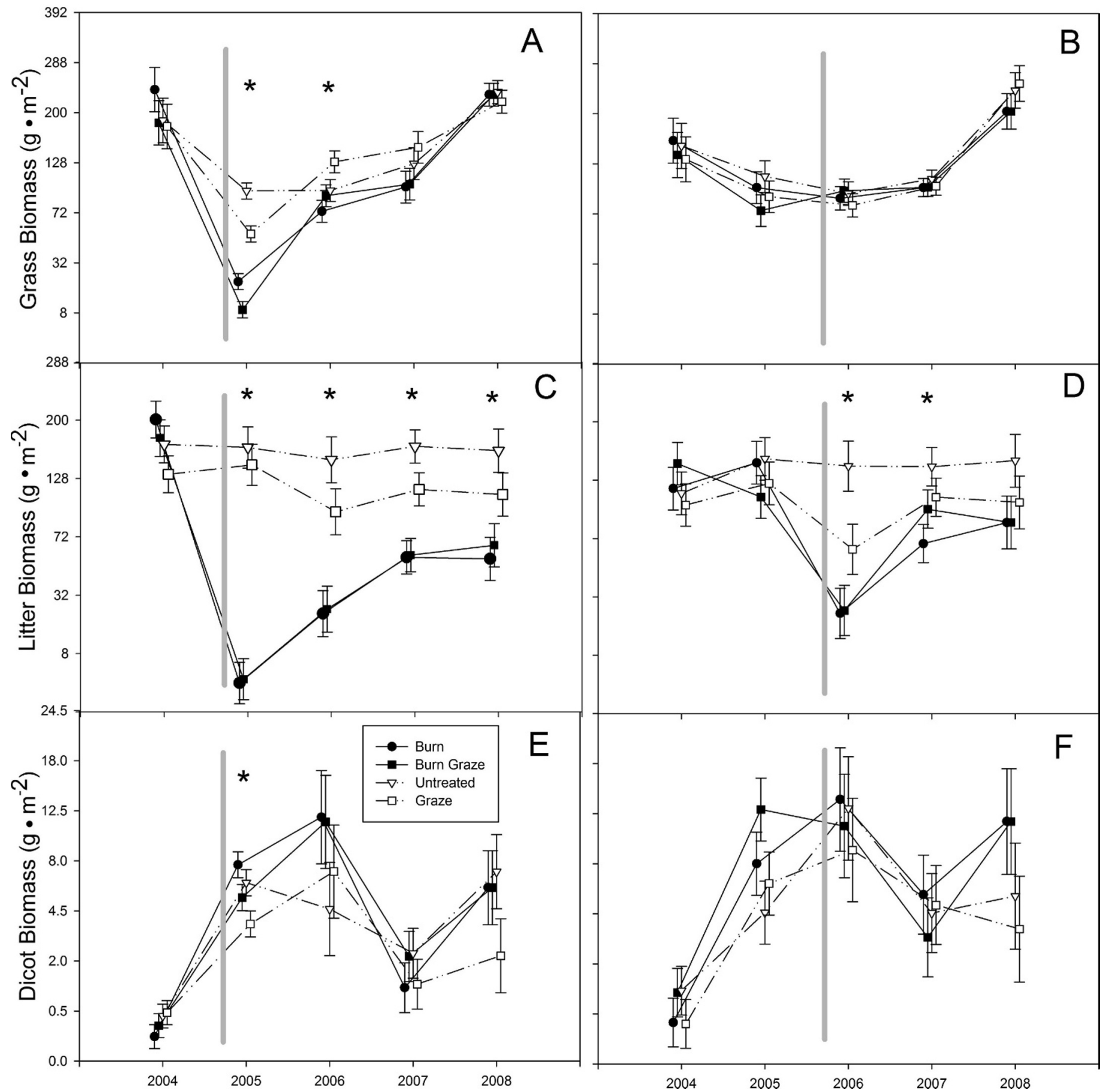

Figure 4. Biomass of grasses (top row), litter (middle row), and dicots (bottom row) treated with prescribed fire, livestock grazing, both prescribed fire and livestock grazing, or were untreated. Treatment symbols are described in Figure 1. Data were square root transformed for analyses, thus yaxis and standard error bars are in geometric scale.

Average biomass on untreated plots was about $350 \mathrm{~g} \cdot \mathrm{m}^{-2}$. Aboveground biomass of dicots most closely followed summer precipitation (Figs. 4E and 4F). Production of litter on untreated plots remained relatively stable throughout the study (Figs. 4C and 4D, dashed line with triangles). Grass biomass on untreated plots corresponded most closely with winter precipitation (Figs. 4A and 4B, dashed line with triangles).
The aboveground biomass of grasses, dicots, and litter changed throughout the study period, regardless of treatment (Table 1), partly due to variation in precipitation. Treatments were most effective at reducing litter, followed by grasses and had limited positive effect on the biomass of dicots (Table 1; Fig. 4). Grasses treated in 2005 showed a significant decrease in aboveground production, but this effect was not present on 
Table 1. Results of repeated measures ANOVA of biomass of different physiognomic groups (herbaceous dicotyledons, grasses, litter) treated with prescribed fire, livestock grazing, or the combination thereof. Bold indicates significance at $P<0.05$.

\begin{tabular}{|c|c|c|c|c|c|c|}
\hline \multirow[b]{2}{*}{ Within } & \multicolumn{3}{|c|}{ Treatments applied 2005} & \multicolumn{3}{|c|}{ Treatments applied 2006} \\
\hline & $\mathrm{F}$ & df (num, den) & $P$ & $\mathrm{~F}$ & df (num, den) & $P$ \\
\hline \multicolumn{7}{|l|}{ Dicots } \\
\hline time & $20.95^{1}$ & $1.65,13.23^{1}$ & 0.0001 & 50.51 & 4,5 & 0.0003 \\
\hline time $\cdot \operatorname{trmt}^{2}$ & $0.97^{1}$ & $4.96,13.23^{1}$ & 0.47 & 1.42 & $12,13.52$ & 0.2665 \\
\hline \multicolumn{7}{|l|}{ Grasses } \\
\hline time & 125.27 & 4,5 & $<0.0001$ & 29.07 & 4,5 & 0.0012 \\
\hline time $\cdot \operatorname{trmt}$ & 5.54 & $12,13.52$ & 0.0019 & 0.52 & $12,13.52$ & 0.8654 \\
\hline \multicolumn{7}{|l|}{ Litter } \\
\hline time & 49.86 & 4,5 & 0.0003 & 20.23 & 4,5 & 0.0027 \\
\hline time $\cdot$ trmt & 3.67 & $12,13.52$ & 0.0126 & 3.54 & $12,13.52$ & 0.0156 \\
\hline
\end{tabular}

${ }^{1}$ Sphericity assumption violated, Greenhouse-Geisser adjustment used.

${ }^{2}$ trmt indicates treatment.

plots treated in 2006 (Fig. 4A vs. 4B). Grasses treated in 2005 showed a significant decrease in production with treatment intensity: burned and subsequently grazed plots had the lowest biomass, followed by burned plots, plots that were only treated with grazing were higher and untreated plots had the highest biomass (Fig. 4A). This effect was short-lived; 2 yr after treatment biomass on all plots was not significantly different.

Burning treatments had the longest-lasting effect on the biomass of litter, as plots that were burned or burned and grazed in 2005 had a significantly lower biomass than unburned plots for the duration of the study. However, plots treated in 2006 only showed a significant decline in litter production for $2 \mathrm{yr}$, due to above-average rainfall shortly after treatments were implemented.

\section{Richness and Diversity}

Throughout the $5 \mathrm{yr}$ of this study, a total of 136 species were documented during fall sampling events and 134 species during the spring, with 56 species common between the two seasons. Richness in the spring was modestly correlated with richness the previous fall $\left(r^{2}=0.53\right)$. Rainfall patterns produced the greatest differences in richness, i.e., low value of richness across all treatments in spring 2006 was due to winter precipitation being $80 \%$ below average. At the end of the study, differences in richness between treatments, on average, were not significant.

The rarest species, all species encountered only once $(n=52)$ out of over 100000 total points, were removed before diversity analyses. Many of these specimens were damaged or impossible to accurately identify. Shannon's and Simpson's diversity measures were highly correlated $\left(r^{2}=0.89\right)$, so only reports of Shannon's index are given. Diversity on all plots was negatively correlated with proportion of Lehmann lovegrass for all four treatments $(P<0.028)$. Diversity and richness varied between years for plots treated in 2005 and 2006 (RMANOVA $P<0.004,<0.0007$, respectively). Treatments were effective at altering diversity (Table 2), with burned-and-then-grazed plots showing the largest, most consistent and most frequent declines in diversity and richness (data not shown). Diversity was also positively correlated with precipitation (Table 2), which caused significant variation between years.
Richness varied with season of sampling; more species were observed in fall than spring, possibly due to more consistent summer precipitation throughout the study period (Fig. 3). Richness in the spring was not significantly affected by treatments the previous summer, possibly because $8 \mathrm{mo}$ and two rainy seasons (summer and winter) had elapsed between the treatments and spring sampling.

\section{DISCUSSION}

Scientists and practitioners are concerned about a positive feedback cycle between fire and nonnative invasive grasses in areas throughout the world. In a semiarid grassland in southwestern North America, fire did not contribute to

Table 2. Results of multiple regression with diversity (Shannon's index, $\mathrm{H}$ ) as response and proportion of Lehmann lovegrass, season of sampling (fall or spring), year of treatment (2005 or 2006), treatment, year, and seasonal precipitation (winter and summer see Fig. 2) as explanatory variables. Estimates of the regression coefficient are given when appropriate. Bold indicates significance at $P<0.05$.

\begin{tabular}{|c|c|c|c|c|}
\hline Effect & Estimate & $\mathrm{F}$ & $\mathrm{df}$ & $P$ \\
\hline Prop $\mathrm{LL}^{1}$ & -0.888 & 186.85 & 1 & $<0.0001$ \\
\hline Season & -0.127 & 57.2 & 1 & $<0.0001$ \\
\hline Year of trmt & 0.058 & 23.45 & 1 & $<0.0001$ \\
\hline Treatment & & 10.48 & 3 & $<0.0001$ \\
\hline Year & -0.022 & 5.85 & 1 & 0.0165 \\
\hline Precipitation & 0.022 & 146.08 & 1 & $<0.0001$ \\
\hline Season·prop LL & 0.086 & 1.07 & 1 & 0.3 \\
\hline Season $\cdot$ year & -0.028 & 9.53 & 1 & 0.0023 \\
\hline Season $\cdot$ precip & -0.008 & 21.65 & 1 & $<0.0001$ \\
\hline Prop LL $\cdot$ trmt & - & 6.43 & 3 & 0.0004 \\
\hline Year $\cdot$ trmt & - & 3.14 & 3 & 0.0264 \\
\hline Year of trmt $\cdot$ trmt & - & 1.75 & 3 & 0.16 \\
\hline Trmt $\cdot$ precip & - & 0.62 & 3 & 0.6 \\
\hline Precip · prop LL & 0.002 & 0.12 & 1 & 0.72 \\
\hline
\end{tabular}

${ }^{1}$ Prop LL indicates proportion of Lehmann lovegrass; trmt, treatment; precip, precipitation. 
increased cover of the dominant nonnative invasive grass alone or in combination with livestock grazing.

Fire led to increased cover of native grasses (Fig. 2A), if a grass/fire cycle were to develop the opposite would result (postulate 3), although this response was highly contingent on pre- and post-treatment patterns of precipitation. In addition, fire led to a decrease in cover of the invasive Lehmann lovegrass (Figs. 1A and 1C), the opposite of postulate 4. Timing and extent of precipitation had significant impacts on community response to treatments, in an expected manner. Specifically, fire produced greater reductions in cover, and the recovery from fire took longer when treatments were implemented in 2005, which was a dry year, than in 2006, which received aboveaverage precipitation. Notably, precipitation was variable to the extreme during the course of this study, with record seasonal drought followed by near-record abundance (Fig. 3). This variation in rainfall had a significant effect on biomass, richness and diversity between years, especially in the spring when winter rainfall was sparse. Such variable patterns of climate extremes are likely to increase in the future (Field et al. 2007; Seager et al. 2007).

The ability of a nonnative species to alter the fire regime depends in some cases on the match in physiognomy between the introduced organism and the community it occupies. We suggest employing a nuanced approach when discussing positive feedbacks and the grass/fire cycle to acknowledge that nonnative grasses differ in their ability to impact fire regimes. This approach is analogous to the effects of nonnative species on communities in general: a few invasive species are transformative, while most are insipid (Pimentel 2002). The grass/fire cycle can be modeled by a gradient in which nonnative grasses transform the occupied plant community's fire regime at one extreme, whereas they cannot persist in the presence of fire at the other extreme. This nonnative grass does not appear to be altering the fire regime, and is not creating a grass/fire cycle in semiarid grasslands in southern Arizona (Bock and Bock 1992), which is consistent with results from a semiarid grassland in Hawaii (Daehler and Goergen 2005), where the invasive and native grasses also have similar physiognomy.

Changes in fire frequency and extent may not occur in the presence of nonnative invasive grasses because historical fires in semiarid grasslands had a large extent and relatively high frequencies, possibly ranging from every few years (Bock and Bock 1978; Frost 1998) when rainfall does not limit production of fine fuel to several decades (Bahre 1991; McPherson 1995) where and when rainfall is low. Fire in semiarid ecosystems correlates with annual to decadal climate patterns, at least on regional scales (Westerling and Swetnam 2003). In addition, increased fire occurrence and extent are not associated with drought conditions in semiarid areas, but rather with periods of above-average precipitation (Crimmins and Comrie 2004). In short, semiarid grasslands are fuel-limited communities. Thus, although nonnative grasses produce more biomass than native grasses (postulate 1), this increase in fuel would have to act as a surrogate for above-average precipitation to overcome the paucity of years with above-average precipitation and therefore to account for increased fire frequency or extent (postulate 2). In this study grass biomass decreased with decreasing precipitation (Figs. 4A and 4B), which lends some evidence against postulate 2 , an altered fire regime due to increased biomass, but this is certainly not sufficient evidence to reject this postulate. The pattern of Lehmann lovegrass increasing fuels and subsequently altering the fire regime is currently undocumented and requires further investigation.

Although two studies have demonstrated increased postfire abundance of Lehmann lovegrass (Cable 1965; Martin 1983), our research is consistent with many more studies that find a lack of evidence to support a grass/fire cycle, postulates 3 and 4 (Humphrey and Everson 1951; Pase 1971; Cox et al. 1988; Bock and Bock 1992; Biedenbender and Roundy 1996; McGlone and Huenneke 2004; Geiger 2006). In addition, the low diversity found in invaded plots can occur without the effects of fire. The unusual but regionally influential results reported by Cable (1965) and Martin (1983) may be attributed to their comparison of fire-tolerant nonnative grasses to fireintolerant native grasses, and their measurement of plant density instead of cover. Increased plant density is consistent with enhanced seedling germination of Lehmann lovegrass as a result of canopy removal (Sumrall et al. 1991). However, this increase in density does not translate into community change beyond the transient seedling phase, as the postfire survival of individual native grasses is twice as high as the survival of Lehmann lovegrass (McDonald 2009). Lehmann lovegrass produces more biomass and grows faster than native grasses, albeit at the cost of lower postfire survival on an individual plant basis. Thus, the vast majority of evidence points to the absence of a positive feedback with Lehmann lovegrass and fire.

Nonnative grasses can alter the severity and intensity of a fire regime in some ecosystems by creating conditions to which native plants are poorly adapted (Brooks et al. 2004; Zouhar et al. 2008). Although Lehmann lovegrass produces more biomass than native grasses, and could increase fire temperatures (Wright and Bailey 1982) to a greater extent than native grasses, these conditions apparently are not outside of historic variability to which native species evolved. Fire behavior is highly erratic over large and small scales due to site and fuel characteristics, and this variation undoubtedly exceeds variation due to above-ground biomass (Daubenmire 1968; Wright and Bailey 1982). If fire temperatures were elevated in these fires they were not extreme enough to kill native grasses. Native grass cover increased after fire because the postfire survival of native grasses exceeds that of Lehmann lovegrass and many native grasses can withstand intense fires produced by a variety of conditions (McDonald 2009).

Practitioners are well aware that grazing some semiarid grass species with livestock soon after fire can be detrimental to longterm grass survival (Bunting et al. 1998) and a 2-yr rest in arid and semiarid areas is recommended (Stoddard et al. 1975). In more mesic areas fire can be used to increase grass production and posttreatment grazing is desired (Fuhlendorf and Engle 2001). However, the purpose of these postfire grazing treatments was to induce a higher mortality on Lehmann lovegrass than by burning alone, since Lehmann lovegrass emerges from dormancy faster and can produce more biomass per unit time than native grasses. Postfire grazing treatments were not effective at further reducing Lehmann lovegrass abundances (Fig. 1A, solid line with squares) and postfire grazing was detrimental to native grasses in most cases 
(Fig. 2A, solid line with circles vs. solid line with squares). These results accord with previous research: livestock preferentially graze native grasses over Lehmann lovegrass in mixedspecies communities (Martin 1983). In contrast, burning without grazing was relatively beneficial to native grasses. Postfire grazing treatments had no detectable effect on herbaceous dicots, a result that may be attributable to the small and transient populations of this guild of species. These results add to the growing literature that grazing benefits Lehmann lovegrass to the detriment of native grasses and grazing may enhance, but is not completely responsible for, its dominance and spread (Galt et al. 1969; Wright and Dobrenz 1973; Fourie and Roberts 1976 cited in Cox et al. 1990; Cox and Ruyle 1986; Anable et al. 1992; McClaran and Anable 1992).

\section{IMPLICATIONS}

Early summer fire can be applied to large areas at relatively low cost and represents one of the very few management options that selectively reduces abundances of Lehmann lovegrass, albeit temporarily. The addition of grazing after fire did not induce further mortality on Lehmann lovegrass and negated the positive effects of burning on native grasses and dicots. The absence of a positive feedback cycle between fire and Lehmann lovegrass suggests that managers can benefit from a diverse assemblage of grasses on their range. Fire does not appear to promote a grass/fire cycle in this system where the invasive grass and the native grasses have similar morphological types. Fire can be an effective management tool because it can increase native grass cover, decrease Lehmann lovegrass cover, and reduce subshrubs, although these results can be short-lived. Depending on management goals and climate patterns, a return interval of approximately every $5 \mathrm{yr}$ to several decades could provide ample time for biomass and subshrub recovery after fire. Shorter intervals could decrease subshrub abundances, but run the risk of not providing enough livestock forage during a drought, if livestock grazing were part of a management plan. Longer intervals could allow increases in Lehmann lovegrass because it outcompetes native grasses in the absence of fire. Additional research would be necessary to test these hypotheses. Perhaps most importantly, it is increasingly clear that the introduction of Lehmann lovegrass in southern Arizona alters the fire regime of rangelands significantly less than other human alterations (Barhe 1991; McPherson 1995; McPherson and Weltzin 2000).

\section{LITERATURE CITED}

Anable, M. E., M. P. McClaran, and G. B. Ruyle. 1992. Spread of introduced Lehmann lovegrass Eragrostis lehmanniana Nees. in southern Arizona, USA. Biological Conservation 61:181-188.

BaHre, C. J. 1991. A legacy of change. Historic human impact on vegetation of the Arizona borderlands. Tucson, AZ, USA: University of Arizona Press. $231 \mathrm{p}$.

Biedendender, S. H., And B. A. Roundy. 1996. Establishment of native semidesert grasses into existing stands of Eragrostis lehmanniana in southeastern Arizona. Restoration Ecology 4:155-162.

Bock, C. E., AND J. H. Bock. 1978. Response of birds, small mammals, and vegetation to burning sacaton grasslands in southeastern Arizona. Journal of Range Management 31:296-300.
Bock, C. E., J. H. Bock, K. L. Jepson, and J. C. ORtega. 1986. Ecological effects of planting African lovegrasses in Arizona. National Geographic Research 2:456-463.

Bock, J. H., AND C. E. Bock. 1992. Vegetation responses to wildfire in native versus exotic grassland. Journal of Vegetation Science 3:439-446.

Breckenfeld, D. J., And D. Robinetr. 2003. Soil and ecological sites of the Santa Rita Experimental Range. In: M. P. McClaran, P. F. Ffolliott, and C. B. Edminster [TECH. COORDS.]. Proceedings: Santa Rita Experimental Range: 100 years (1903 to 2003) of accomplishments and contributions. Ogden, UT, USA: US Department of Agriculture, Forest Service, RMRS-P-30. p. 157-165.

BRooks, M. L. 1999. Alien annual grasses and fire in the Mojave Desert. Madroño 46:13-19.

Brooks, M. L., C. M. D’Antonio, D. M. Richardson, J. M. DiTomaso, J. B. Grace, R. J. Hobbs, J. E. Keeley, M. Pellant, and D. Pyke. 2004. Effects of invasive alien plants on fire regimes. Bioscience 54:677-688.

Buffington, L. C., And C. H. Herbel. 1965. Vegetational changes on a semidesert grassland range from 1858 to 1963. Ecological Monographs 35:139-164.

Bunting, S. C., R. Robberecht, And G. E. Defosse. 1998. Length and timing of grazing on postburn productivity of two bunchgrasses in an Idaho experimental range. International Journal of Wildland Fire 8:15-20.

CABLE, D. R. 1965. Damage to mesquite, Lehmann lovegrass and black grama by a hot June fire. Journal of Range Management 18:326-329.

Cox, J. R. 1984. Temperature, timing of precipitation and soil texture effects on germination, emergence and seedling survival of South African lovegrasses. South African Journal of Botany 50:159-170.

Cox, J. R., M. H. Martin, F. A. Ibarra, J. H. Fourie, J. F. G. Rethman, and D. G. Wilcox. 1988. The influence of climate and soils on the distribution of four African grasses. Journal of Range Management 41:127-139.

Cox, J. R., AND G. B. Ruyle. 1986. Influence of climatic and edaphic factors on the distribution of Eragrostis lehmanniana Nees in Arizona, USA. Journal of the Grassland Society of Southern Africa 3:25-29.

CRIDER, F. J. 1945. Three introduced lovegrasses for soil conservation. US Department of Agriculture Circular 730.

Crimmins, M. A., And A. C. Comrie. 2004. Interactions between antecedent climate and wildfire variability across southeastern Arizona. International Journal of Wildland Fire 13:455-466.

Daehler, C. C., and E. M. Goergen. 2005. Experimental restoration of an indigenous Hawaiian grassland after invasion by buffel grass (Cenchrus ciliaris). Restoration Ecology 13:380-389.

D'Antonio, C. M., And P. M. Vitousek. 1992. Biological invasions by exotic grasses, the grass/fire cycle, and global change. Annual Review of Ecology and Systematics 23:63-87.

Daubenmire, R. 1968. Ecology of fire in grasslands. Advances in Ecological Research 5:209-266.

Esque, T. C., and C. R. Schwalbe. 2002. Mexican grasslands, thornscrub, and transformation of the Sonoran Desert by invasive exotic buffelgrass (Pennisetum ciliare). In: B. Tellman [ED.]. Invasive exotic species in the Sonoran Region. Tucson, AZ, USA: University of Arizona Press and the Arizona-Sonora Desert Museum. p. 165-194.

Fernandez, R. J., And J. F. Reynolds. 2000. Potential growth and drought tolerance of eight desert grasses: lack of a trade off? Oecologia 123:90-98.

Field, C. B., L. D. Mortsch, M. Brklacich, D. L. Forbes, P. Kovacs, J. A. Patz, S. W. Running, and M. J. Scott. 2007. North America. In: M. L. Parry, O. F. Canziani, J. P. Palutikof, P. J. van der Linden, and C. E. Hanson [Eds.]. Climate change 2007: impacts, adaptation and vulnerability. Contribution of Working Group II to the Fourth Assessment Report of the Intergovernmental Panel on Climate Change. Cambridge, UK: Cambridge University Press. $p$. 617-652.

Fourie, J. H., AND B. R. Roberts. 1976. A comparative study of three veld types of the Northern Cape: species evaluation and yield. Proceedings of the Grassland Society of Southern Africa 11:79-85. Cited by: Cox, J. R., G. B. Ruyle, and B. A. Roundy. 1990. Lehmann lovegrass in southeastern Arizona: biomass production and disappearance. Journal of Range Management 43:367-372.

Frasier, G. W., and J. R. Cox. 1994. Water balance on a pure stand of Lehmann lovegrass. Journal of Range Management 47:373-378. 
Frost, C. C. 1998. Presettlement fire frequency regimes of the United States: a first approximation. In: Proceedings of the 20th Tall Timbers Fire Ecology Conference. Tallahasee, FL, USA: Tall Timbers Research Station. p. 70-81.

Funlendorf, S. D., AND D. M. Engle. 2001. Restoring heterogeneity on rangelands: ecosystem management based on evolutionary grazing patterns. Bioscience $51: 625-632$.

Galt, H. D., B. Theurer, J. H. Ehrenreich, W. H. Hale, and S. C. Martin. 1969. Botanical composition of diet of steers grazing on desert grassland range. Journal of Range Management 22:14-19.

GEIGER, E. L. 2006. The role of fire and a nonnative grass as disturbances in semidesert grasslands of southeastern Arizona [dissertation]. Tucson, AZ, USA: University of Arizona. $131 \mathrm{p}$.

Humphrey, R. R., and A. C. Everson. 1951. Effect of a fire on a mixed grass-shrub range in southern Arizona. Journal of Range Management 4:264-266.

Martin, S. C. 1983. Responses of semiarid grasses and shrubs to fall burning. Journal of Range Management 36:604-610.

McClaran, M. P., and M. E. Anable. 1992. Spread of introduced Lehmann lovegrass along a grazing intensity gradient. Journal of Applied Ecology 29:92-98.

McClaran, M. P., P. F. Ffolliott, and C. B. Edminster [tech. Coords.]. 2003. Proceedings: Santa Rita Experimental Range: 100 years (1903 to 2003) of accomplishments and contributions. Ogden, UT, USA: US Department of Agriculture, Forest Service, RMRS-P-30.

McDonald, C. J. 2009. Management of nonnative perennial grasses in southern Arizona: effects of prescribed fire and livestock grazing [dissertation]. Tucson, AZ, USA: University of Arizona. 163 p.

McGlone, C. M., And L. F. Huenneke. 2004. The impact of a prescribed burn on introduced Lehmann lovegrass versus native vegetation in the northern Chihuahuan desert. Journal of Arid Environments 57:297-310.

McPherson, G. R. 1995. The role of fire in the desert grasslands. In: M. P. McClaran and T. R. Van Devender [EDs.]. The desert grassland. Tucson, AZ, USA: University of Arizona Press. p. 130-151.

McPherson, G. R., and J. F. Weltzin. 2000. Disturbance and climate change in United States/Mexico borderland plant communities: a state-of-the-knowledge review. Fort Collins, CO, USA: US Department of Agriculture, Forest Service. 24 p. RMRS-GTR-50.

Miller, G., M. Friedel, P. Adam, And V. Chewings. 2010. Ecological impacts of buffel grass (Cenchrus ciliaris L.) invasion in central Australia: does field evidence support a fire-invasion feedback? The Rangeland Journal 32:353-365.

PASE, C. P. 1971. Effects of a February burn on Lehmann lovegrass. Journal of Range Management 24:454-456.

Pimentel, D. [ed.]. 2002. Biological invasions: economic and environmental costs of alien plant, animal, and microbe species. Boca Raton, FL, USA: CRC Press. 384 p.

Pimm, S. L., AND J. H. Lawton. 1998. Planning for biodiversity. Science 279:2068-2069.
Rossiter, N. A., S. A. Setterfield, M. M. Douglas, and L. B. Hutley. 2003. Testing the grass-fire cycle: alien grass invasion in the tropical savannas of northern Australia. Diversity and Distributions 9:169-176.

Ruyle, G. B., B. A. Roundy, And J. R. Cox. 1988. Effects of burning on germinability of Lehmann lovegrass. Journal of Range Management 41:404-406.

Schussman, H. R., E. L. Geiger, T. M. Mau-Crimmins, and J. Ward. 2006. Spread and current potential distribution of an alien grass, Eragrostis lehmanniana Nees, in the southwestern USA: comparing historical data and ecological niche models. Diversity and Distributions 12:582-592.

Seager, R., M. F. Ting, I. Held, Y. Kushnir, J. Lu, G. Vecchi, H. P. Huang, N. Harnik, A. Leetmaa, N. C. Lau, C. H. Li, J. Velez (nakamura), and N. Naik. 2007. Model projections of an imminent transition to a more arid climate in southwestern North America. Science 316:1181-1184.

Stoddard, L. A., A. D. Smith, And T. W. Box. 1975. Range management. 3rd ed. New York, NY, USA: McGraw-Hill, Inc. 532 p.

Sumrall, L. B., B. A. Roundy, J. R. Cox, and V. K. Winkel. 1991. Influence of canopy removal by burning or clipping on emergence of Eragrostis lehmanniana seedlings. International Journal of Wildland Fire 1:35-40.

Turner, R. M., R. H. WebB, J. E. Bowers, and J. R. Hastings. 2003. The changing mile revisited: an ecological study of vegetation change with time in the lower mile of an arid and semiarid region. Tucson, AZ, USA: University of Arizona Press. $334 \mathrm{p}$.

Van Auken, 0. W. 2000. Shrub invasions of North American semiarid grasslands. Annual Review of Ecology and Systematics 31:197-215.

Westerling, A. L., and T. W. Swetnam. 2003. Interannual to decadal drought and wildfire in the western United States. Eos Transactions AGU 84:545-560.

Whisenant, S. G. 1990. Changing fire frequencies on Idaho's Snake River plains: ecological and management implications. In: E. D. McArthur, E. M. Romney, S. D. Smith, and P. T. Tueller [EDS.]. Symposium on cheatgrass invasion, shrub die-off, and other aspects of shrub biology and management, Las Vegas. Logan, UT, USA: US Department of Agriculture, Forest Service, Intermountain Research Center. p. 4-10. General Technical Report INT-276.

Wilcove, D. S., D. Rothstein, J. Dubow, A. Phillips, and E. Losos. 1998. Quantifying threats to imperiled species in the United States. Bioscience 48:607-615.

Wright, H. A., And A. W. Balley. 1982. Fire ecology, United States and Southern Canada. New York, NY, USA: Wiley. 528 p.

Wright, L. N., AND A. K. Dobrenz. 1973. Efficiency of water use and associated characteristics of Lehmann lovegrass. Journal of Range Management 26:210-212.

Zouhar, K. S., J. Kapler, S. Sutherland, and M. L. Brooks. 2008. Wildland fire in ecosystems: fire and nonnative invasive plants. Ogden, UT, USA: US Department of Agriculture, Forest Service, Rocky Mountain Research Station, General Technical Report RMRS-GTR-42-vol. 6. 355 p. 